\title{
Good and Caring Teaching Behaviours as Perceived by Business Education Students in Tertiary Institutions in the North Eastern Nigeria
}

\author{
Magnus P. Udo ${ }^{1, *}$, Agatha Samson ${ }^{1} \&$ Abdulmutallib Umar Baraya ${ }^{1}$ \\ ${ }^{1}$ Department of Vocational and Technology Education, Abubakar Tafawa Balewa University (ATBU), Bauchi, \\ Nigeria \\ *Correspondence: Department of Vocational and Technology Education, Abubakar Tafawa Balewa University \\ (ATBU), Bauchi, Nigeria. Tel: 234-705-679-6605. E-mail: jemautong@gmail.com
}

Received: May 27, 2016

Accepted: June 15, 2016 Online Published: July 6, 2016

doi:10.5430/wje.v6n4p14

URL: http://dx.doi.org/10.5430/wje.v6n4p14

\begin{abstract}
This study investigated good and caring teaching behaviours as perceived by Business Education students in Tertiary Institutions in the North Eastern Nigeria. The latter needed good and caring teaching behaviours to reform the education sector that had been devastated by Boko Haram insurgency. The design of the study was survey. The research questions answered were: (i) what knowledge bases do business education students perceived of their Lecturers for good and caring teaching in their institutions?; (ii) What repertoire of best practices do business education students perceived their lecturers have for good and caring teaching in the institutions?; and (iii) what attitude and skills of problem-solving and reflection do the students perceived of their lecturers for good and caring teaching in the tertiary institutions? An instrument of 20 items was distributed to 200 respondents in three tertiary institutions located in the North Eastern Nigeria. Frequency and descriptive statistics were used to analyze the data. The findings of the study revealed, among others, that business education students perceived that their lecturers have control over a knowledge base that guides what they do as Lecturers; that they also perceived that their lecturers have a repertoire of best teaching practices which they have been using to instruct them in the classrooms and to work with fellow workers in the university setting. Lastly they perceived that their lecturers have disposition and skills to approach all aspects of their work in a reflective, collegial and problem-solving manner. It was therefore recommended that the relevant Tertiary Institutional Authorities and government agencies in the North Eastern Nigeria should provide adequate professional training and retraining of Business Education Lecturers in order to help them become good and caring lecturers.
\end{abstract}

Keywords: good; caring; teaching behaviours; perception; business education students

\section{Introduction}

According to Stephen (2015) in Arends (1994), central to the process of learning to teach are concepts and definitions of the "good" and "caring" teacher. Without any doubt, trying to define a good and caring teacher has long occupied the thoughts of many Nigerian citizens, Government Agencies, teachers and professional researchers Stephen (2015) in Arends, (1994). Within the educational community, there has been a remarkable diversity in the definition of good and caring teaching. Some have argued that a good and caring teacher is one who can establish rapport with students and a nurturing, caring atmosphere for personal development (Stephen, 2015). Others have defined a good and caring teacher as a person who has a love for learning and a superior command of a particular academic subject skills and competencies (Stephen, 2015). Still others argue that a good and caring teacher is someone who can trigger students' energy to work hard toward a more just and humane social order (Stephen, 2015). Indeed, the content of a tertiary teacher education curriculum is itself a statement about what good and caring teachers need to know. According to Schiro (2012), a good and caring teacher's job is to make sure that the learners work through curricula and acquire their life-changing performances. Schiro (2012) added that the teacher is the manager of the learning conditions, who both prepares the learning environment for learners and supervises their work in that environment. Schiro (2012) also opined that a good and caring teacher is a supervisor, a director, a guide, a stimulator, of the rank and file of the students in order to bring about on the part of the latter the acquisition of various skills, competencies, knowledge and abilities. 
From the foregoing, it is pertinent to note that good and caring teaching is a peculiar job and as such differs from all other professions. As a good and caring teacher, one plays the roles of an observer and diagnostician of learners, a provider of the instructional environment and a facilitator of students' learning (Schiro, 2012). Indeed, good and caring teachers have to take an involved interest in what the students are doing, and have to become actively involved in the work of each student as one who seeks to help that student realize his/her goals and potentials. This implies that the teachers have to be capable of becoming involved in their students' learning, and be excited about what the students are learning and be able to share their involvement, interest and excitement with their students as they learn. In reality, a good and caring teacher is someone who wears many caps at the same time. For example, one can easily say that a good and caring teacher is a disciplinarian, a conveyor of information, an evaluator, a classroom manager, a counselor, a decision maker and a role-model. In agreement with the above, a teacher in the words of Stephen (2015) can be regarded as one who instructs, directs and guides students for effective change in behavior. She added that a teacher is a professionally qualified person whose duty in an educational institution is to help individuals, students or learners to acquire skills, abilities and competencies. She went on to say that teachers exert a tremendous impact on student's academic achievements, and that teachers vary greatly in their effectiveness and ineffectiveness in the classroom situation. According to Udo, (2012) the positive and negative behaviors exhibited by Business education teachers during classroom teaching determines to a large extent their effectiveness and vice versa in the classroom teaching-learning situation, and ultimately the impact they have on students' learning, skill acquisition and achievement.

The big question now is "what teaching skills are required of a good and caring business education lecturer"? In an attempt to answer this question, Cooper (2014) states that among the skills that many educators believe are essential for good and caring teaching include the following: i) The ability to ask different kinds of questions, each requiring different types of thought processes from the students; ii) The ability to provide effective feedback; iii) The ability to plan instruction and learning activities; iv) The ability to diagnose students' needs and learning difficulties; v) The ability to vary the learning situation to keep the students involved; vi) The ability to recognize when students are paying attention and to use this information to vary behaviour and, the direction of the lesson; vii) The ability to use technological equipment such as computers to enhance student learning; viii) the ability to assess student learning and ix) The ability to differentiate instruction based on the students' experiences, interests and academic abilities. This list of teaching skill is far from being complete; it does suggest that good and caring teachers need a large repertoire of skills to work effectively with students with varying background and different educational experiences. Other teaching skills required by business education lecturers for good and caring teaching include outlining the lesson objectives and sequence and sticking to them, presenting the lesson content systematically, summarizing key points as well as clearly delineating major transitions between ideas or topics (Cooper, 2014). Similarly, Stephen (2015) views a good and caring teaching as maximizing students' skill acquisition, academic attainment and course satisfaction. Schiro (2012) states that a good and caring teaching is that kind of teaching that is well organized and presented clearly and enthusiastically with opportunities for students' participation. A good and caring teaching can contribute to the students' understanding of the lesson and can help them to improve skills and abilities and develop in them more desirable attitudes.

A good and caring teaching is aimed at helping business education students to achieve the objectives set for a given teaching and learning situation. This is also affected by a number of factors such as the teacher, student and environmental factors. The teacher who is the leader of the learning environment should manipulate the student and the environment to make the learning effective in skill acquisition. Educational institutions are to directly serve students and be responsible to students' learning needs. They should improve the effectiveness of students' learning outcomes if they first establish what the students perceived should be for a good and caring teaching.

Furthermore, Stephen (2015) argued that for the reason that students are the people at the receiving end of the teaching-learning process; they should have perceptions of good and caring teaching as well as whom a good and caring teacher really is. According to her study, the characteristics of good and caring teachers include being specific, precise, avoiding vagueness, being friendly, helpful, humane, involving students in the teaching learning situation, respecting students, preparedness, fairness, knowledgeable, good lesson delivery, motivating the business students and enjoying one's work.

A Good and caring teaching in the area of business education courses have been a continuing concern to business education students especially as they learn skill courses like Shorthand, word-processing, accounting and information technology and management. This concern is enlarged as the teaching of business subjects becomes more and more complicated in today's society. The socio-psychological notion of feedback has crept into research in education because both researchers and practicing teachers stand to gain from knowing about the feeling of their students 
towards their activities (Stephen, 2015). Other strong proponents of students' evaluation of their teachers have stressed that such a practice while providing a source of diagnostic feed-back to teachers, may also reveal the criteria used in promoting decisions and constitute a source of information for students to be used in selection of subjects and teachers (Stephen, 2015). Studies have revealed that, teachers who received feed-backs concerning their teaching behaviors from students showed greater gains in subsequent ratings than teachers who received no feedbacks. (Cooper, 2012). The issues of partnering with stakeholders in the teaching-learning situation works well when business education students contribute in expressing what a good and caring teaching behaviour is. However, there may also be biases in students' perceptions as respondents to good and caring teaching behaviours; yet there is a dearth of literature in this area especially the North Eastern Nigeria, which had been badly affected by Boko Haram insurgency. It is in view of the impacts that good and caring teaching behaviors have on the teaching and learning process that motivated the researchers to carry out this study in tertiary institutions in the North Eastern Nigeria.

\section{Statement of the Problem}

This study examined good and caring teaching behaviours of Business Education Lecturers as perceived by their students in tertiary institutions in the North Eastern Nigeria. The latter is that area of Nigeria that had suffered terrible academic and economic setbacks because of Boko Haram insurgency. Boko Haram simply means Western education or non-Islamic education is a "sacrilege" or "a sin". The group has been active in the North Eastern Nigeria since 2009. Their members want to impose Islamic law as the only law in the entire nation of Nigeria. This is because the group itself is an Islamic militant group which believes that politics in northern Nigeria has been seized by a group of corrupt, false Muslims. Their members are waging a war against them, and the Federal Republic of Nigeria generally in order to create a "pure" Islamic state that will be ruled by sharia law. As a result of the negative effects of the Boko Haram insurgency, many schools and colleges were burnt down and some students kidnapped. For instance, over two hundred school girls were kidnapped in Chibok, Borno State, Nigeria. Still in the same area, other innocent College students were slaughtered in their sleep by the same militant group. Indeed, Nigeria as a nation lost a good number of citizens because of Boko Haram insurgency. Apart from schools, colleges and universities, other public places such as the Common Wealth Building in Abuja, the capital city was destroyed, market places, Churches and Mosques were destroyed. Generally speaking, the students in the North Eastern Nigeria could not go to school for some months and this affected them seriously. Now that the insurgency has been fought and degraded by General Muhammadu Buhari led administration, and the schools and colleges in this region of Nigeria have started again, there is a need for the school system to be made lively and comfortable for the students through good and caring teaching behaviours. This is because the latter affect students' learning, conduct and emotion (Ellis and Tod, 2009). According to Jordan, Carlile and Stack (2008) perception is the process by which we interpret, and make sense of the things that are presented to our senses. When business education students in the research area perceived that the teaching behaviours that their lecturers bring into the teaching-learning situation are not conducive enough to them; that would make them to remember the terrible impacts of the Boko Haram insurgency on their lives and their schooling. Consequently, they begin to complain that their lecturers are not teaching them well. Following this, heads of business education departments, and deans of schools or faculties often received anonymous letters from students complaining about some of their lecturers not teaching them well. Although continuous and steady efforts have been made by researchers and school administrators to determine the characteristics of good and caring teachers, the real issues concerning what their characteristics are, how to determine them, and how to utilize them have remained controversial issues. Notwithstanding the fact that most business education lecturers undergo similar professional and pedagogical training while in their tertiary institutions, yet it appears not all of them had grasped very well the science of good and caring teaching. Consequently, there appears to be some kinds of inequality in the teaching behaviours of business education lecturers. As a result of this, Business education students perceived that some of their lecturers are extremely poor in teaching them and that they are the ones who suffer the bad effects of their poor teaching. This study therefore examined good and caring teaching behaviours of business educators from the viewpoints of business education students in tertiary institutions in the North Eastern Nigeria.

\section{Purpose of the Study}

The major purpose of this study was to identify good and caring teaching behaviours of Business education Lecturers as perceived by their students in tertiary institutions in the North Eastern Nigeria. Specifically, the study identified good and caring teaching behaviours of the Lecturers such as: 
1. The knowledge bases that business education students perceived of their Lecturers for good and caring teaching.

2. The repertoire of best practices that the students perceived their lecturers have for good and caring teaching.

3. The attitude and skills of problem solving and reflection that students perceived of their lecturers for good and caring teaching.

\section{Research Questions}

The study was guided by the following research questions:

1. What knowledge bases do business education students perceived of their Lecturers for good and caring teaching in their tertiary institutions?

2. What repertoire of best practices do business education students perceived their lecturers have for good and caring teaching in the institutions?

3. What attitude and skills of problem solving and reflection do students perceived of their lecturers for good and caring teaching behaviours in their institutions?

\section{Significance of the Study}

The findings of this study will highlight how Business education Lecturers could carry out good and caring teaching behaviours among their students which in turn will ginger them to go and do the same to other business students that they will teach after graduation from the colleges and universities. Such good and caring teaching behaviours can be adopted by both business education lecturers and their students to boost the teaching and learning of business education courses nationwide. Furthermore, the students from the North Eastern Nigeria require very good and caring teaching behaviours from their lecturers as something to console, soothe and give them conducive and friendly learning environments in order to lessen the effect of Boko Haram insurgency that had devastated the Educational Institutions in this geo-political zone for some years now.

\section{Method of Study}

\subsection{Research Design}

The study employed the quantitative research approach because it is an excellent way of finalizing results and proving or disproving good and caring teaching behaviours of Business Education Lecturers as perceived by their students in three universities in the North Eastern Nigeria. The justification for this choice was that quantitative structure remains unchanged for centuries, so also is its standard across many scientific fields and disciplines. In addition, the use of quantitative method helped to sieve out external factors on the perception of the business education students, and so the results gained were seen as genuine and unbiased. Therefore descriptive survey method was used to examine the frequencies and percentages to give meaning to figures on good and caring teaching behaviours of Business Education Lecturers as perceived by their students. Data for the study was collected mainly from Business Education Lecturers and their students and where there was the need for clarification, the researchers took their time to do so.

\subsection{Study Population and Sample}

The population of the study consisted of all the final year Business education students and their lecturers in the Department of Vocational and Technology Education of three tertiary institutions in the North Eastern Nigeria namely, Abubakar Tafawa Balewa University, Bauchi, Adamu Moddibo University of Technology, Yola and University of Maiduguri, Maiduguri, Borno State. The sample for the study comprised thirty (30) business education lecturers and one hundred and seventy (170) business education students who were randomly drawn from the three business education units of the Department of Vocational and Technology Education in the three tertiary institutions. The study adopted a survey research design. It elicited information from the respondents in the three tertiary institutions in the Northern Eastern Nigeria.

\subsection{Instrument Description}

The instrument which was used for data collection was a structured questionnaire which was developed after a thorough literature review based on the research questions raised for the study. Frequency and simple percentages were used for the analysis of data collected from the respondents. Any item statement that scored an average of fifty percent $(50 \%)$ and above was accepted as being good and caring teaching behaviours according to perception of 
business education students on their lecturers. On the contrary, any item statement that scored below fifty percent $(50 \%)$ was regarded as being poor teaching behaviours by business education lecturers from the point of view of their students' perception.

\section{Results}

Good and caring teaching behaviours in the North Eastern Nigeria is absolutely necessary for effective teaching and learning to occur. As a result of the fact that the whole study area is just coming out of Boko Haram insurgency, Business Education Lecturers here need to provide enabling environments for the students to learn well and enjoy their studies. The results of the findings are presented in the table below.

Table 1. Good and Caring Teaching Behaviours of Lecturers as Perceived by Business Education Students in Tertiary Institutions in the North Eastern Nigeria

\begin{tabular}{|c|c|c|c|}
\hline $\mathrm{S} / \mathrm{N}$ & Item Statements & Frequency & Percentages \\
\hline & 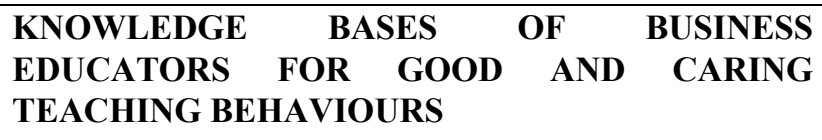 & & \\
\hline 1. & $\begin{array}{l}\text { Business Educators have to know their subjects } \\
\text { thoroughly. They should be soaked in them, eat them, } \\
\text { sleep them and dream them. }\end{array}$ & 185 & $92.5 \%$ \\
\hline 2. & $\begin{array}{l}\text { Pedagogical Content Knowledge, that is, the special } \\
\text { amalgam of content and pedagogy that is uniquely the } \\
\text { province of business educators, their own special form of } \\
\text { professional understanding. }\end{array}$ & 188 & $94.0 \%$ \\
\hline 3. & Knowledge of business students and their characteristics & 190 & $95.0 \%$ \\
\hline 4. & $\begin{array}{l}\text { Knowledge of educational ends, purposes, and values } \\
\text { and their philosophical and historical backgrounds }\end{array}$ & 179 & $89.5 \%$ \\
\hline 5. & $\begin{array}{l}\text { Knowledge of State and Federal Government educational } \\
\text { contexts, ranging from the workings of the group or } \\
\text { classroom, to the governance and financing of education, } \\
\text { to the character of communities and cultures }\end{array}$ & 149 & $74.5 \%$ \\
\hline 6. & $\begin{array}{l}\text { Curriculum knowledge, with particular grasp of the } \\
\text { materials and programmes that serve as 'tools of the } \\
\text { trade' for business educators }\end{array}$ & 170 & $85.0 \%$ \\
\hline \multirow[t]{2}{*}{7.} & Knowledge of Classroom Management & 169 & $84.5 \%$ \\
\hline & 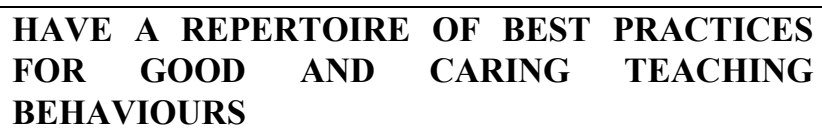 & & \\
\hline 8. & $\begin{array}{l}\text { Business educators have multi-talent teaching } \\
\text { approaches which are appropriate and the selection of } \\
\text { any approaches should depend on the lecturers' goals and } \\
\text { the characteristics of a specific group of learners }\end{array}$ & 167 & $83.5 \%$ \\
\hline 9. & $\begin{array}{l}\text { Business Educators are to provide leadership to their } \\
\text { group of students }\end{array}$ & 145 & $72.5 \%$ \\
\hline 10. & $\begin{array}{l}\text { Business educators are to provide direct, face-to-face } \\
\text { instruction to their students }\end{array}$ & 158 & $79.0 \%$ \\
\hline 11. & $\begin{array}{l}\text { Business Educators are expected to work with students, } \\
\text { fellow colleagues, tertiary institutions' authorities, } \\
\text { parents and others in order to achieve good and effective } \\
\text { teaching }\end{array}$ & 179 & $89.5 \%$ \\
\hline
\end{tabular}




\section{REFLECTION AND PROBLEM-SOLVING SKILLS FOR GOOD AND CARING TEACHING BEHAVIOURS}

\begin{tabular}{|c|c|c|c|}
\hline 12. & $\begin{array}{l}\text { Good and effective business education lecturers are } \\
\text { people who learn to approach unique and unfamiliar } \\
\text { teaching situations with a problem-solving orientation }\end{array}$ & 160 & $80.0 \%$ \\
\hline 13. & $\begin{array}{l}\text { They should learn the art of good and effective teaching } \\
\text { through reflection about their practices. }\end{array}$ & 170 & $85.0 \%$ \\
\hline 14. & $\begin{array}{l}\text { They should be very thoughtful and more insightful than } \\
\text { average people. }\end{array}$ & 150 & $75.0 \%$ \\
\hline 15. & They should very friendly and mutually respectful. & 145 & $72.5 \%$ \\
\hline 16. & Business Educators should be analytical in the teaching. & 190 & $95.0 \%$ \\
\hline 17. & $\begin{array}{l}\text { They should be able to spontaneously respond with } \\
\text { concern to their students' needs, desires and messages. }\end{array}$ & 160 & $80.0 \%$ \\
\hline 18. & $\begin{array}{l}\text { Business educators should always have positive attitude } \\
\text { towards their students by treating them fairly }\end{array}$ & 170 & $85.0 \%$ \\
\hline 19. & $\begin{array}{l}\text { Business educators' attitude towards the students and } \\
\text { their parents can help to enhance their effectiveness }\end{array}$ & 150 & $75.0 \%$ \\
\hline \multirow[t]{2}{*}{20.} & $\begin{array}{l}\text { Positive attitude of the lecturers towards students during } \\
\text { lessons help to make them perceived the lecturers are } \\
\text { teaching them well. }\end{array}$ & 149 & $74.5 \%$ \\
\hline & $\begin{array}{l}\text { The Table above shows the Perceptions of Business } \\
\text { Education Students on their Lecturers concerning } \\
\text { their Teaching behaviours }\end{array}$ & & \\
\hline
\end{tabular}

\section{Discussions of Findings}

One of the findings on the knowledge bases of Business education lecturers perceived by their students is that they should know their business education courses thoroughly; they should be soaked in them, eat them, sleep in them and dream them. This talks about maximum mastery of content knowledge of the particular business subjects to be taught to their students such as accounting, management, marketing, banking and finance, office technology and management, economics, business and commercial law and all other old and new business courses in the tertiary institutions' curriculum. According to Udo (2014), business education lecturers should master these business education courses to the level of automaticity to the extent that they could teach them easily and without much sweat. Another finding on the knowledge bases of Business educators perceived by their students for good and effective teaching is that of didactic or pedagogical content knowledge. Here, the business education students perceived that their Lecturers are equipped with very rich methods of teaching for good and effective teaching in their tertiary institutions. This addresses the special blend of content and pedagogy that is outstandingly the territory of the business education lecturers and indeed their special form of professional understanding. It is the perception of the business students that their lecturers are familiar with appropriate strategies of teaching accounting, shorthand, computer keyboarding skills, marketing, ICT and a spectrum of all other business courses and could use these strategies to teach them effectively. According to Cooper (2010) prospective teachers need to understand the content of the subjects they teach as well as the methods of teaching the specific content. In agreement with the above, Cooper (2010) opined that teachers need to understand the subjects they teach well enough to analyze, and convey their elements, logic, possible uses and social biases. The teachers need to understand their school curriculum and the pedagogical content knowledge. The next finding on the knowledge bases of business education lecturers perceived of the students for good and effective teaching is that they should get to know them better and their characteristics also. This is because the better they know them - their background, social, personal and emotional problems, the better they would be able to assist them. They should recognize how previous teaching could sufficiently prepare them for the next level of teaching. The students perceived that their business education lecturers could adopt multi-talents approach which would involve teaching them to have love, interest and affection for what is taught and 
helping them to transfer what has been taught into practical terms. The fact that business education students perceived their lecturers have knowledge of educational ends, purposes, and values and their philosophical and historical backgrounds is another finding which indicates that they could teach them effectively. Other findings on the knowledge bases of the lecturers include the use of good class management techniques, curriculum knowledge and all issues affecting the administration and financing of education by the State and Federal Government. The business education students perceived that these issues could go a long way to affect good and effective teaching of business courses by their lecturers.

Having a repertoire of best practices for good and caring teaching behaviours is another finding that business education students perceived of their lecturers in the three tertiary institutions where this study was conducted. The study revealed that the students perceived that their good and effective lecturers have diverse repertoires of best teaching strategies and that they are not restricted to just a few of them. They perceived that their lecturers have a repertoire for three aspects of teaching. The first is that the lecturers provide leadership to all business education students. The latter perceived that their lecturers are to manage, control and establish procedures for effective motivation, and to coordinate good and effective teaching of their business courses. These talk about the executive functions of teaching. In addition to the executive functions of teaching, business education students further perceived that their lecturers are in the tertiary institutions to provide direct, face-to-face instructions to them and this of course is concerned with the interactive function of teaching. They also perceived that their lecturers are expected to work with fellow colleagues, students, parents and others to perform the institutional functions of teaching.

The business education students further perceived that their lecturers have incredible dispositions and skills to enable them approach all aspects of their teaching job in a reflective, collegial and problem-solving manner. They said they perceived that their lecturers have multi-talented teaching strategies which when used appropriately could bring about good and effective teaching behaviours. As earlier Stephen (2015) opined in her study, the characteristics of good and effective teachers include being specific, precise, avoiding ambiguity, being friendly, helpful, humane, involving students in the teaching learning situation, respecting the students, watchfulness, fairness, knowledgeable, good lesson delivery, motivating the business students and having a passion for one's work; this study agrees that business education lecturers should do everything possible to enhance a good and effective teaching and learning of business education courses in our tertiary institutions.

\section{Conclusion}

The different aspects of good and caring teaching behaviours have been identified in this study. These included the fact that business education students perceived that good and caring business education lecturers have sound and brilliant knowledge bases on the teaching and learning of their courses, that they have multi-talented teaching strategies to bring about good and caring teaching of their courses and that they have incredible dispositions and skills to approach all aspects of their teaching jobs in a reflective, collegial and problem-solving manner. In the aspect of repertoire of best practice, all business education lecturers should make efforts to ensure that at all times good and caring teaching of business education courses take place in their tertiary institutions.

\section{Recommendations}

The researchers put forward the following recommendations in order to improve the teaching and learning of business education courses in our nation's tertiary institutions especially in the North Eastern Nigeria.

1. The Business Education Lecturers should prepare their lessons adequately before going to deliver their lessons.

2. They should upgrade the knowledge base of any business education courses that they are teaching.

3. The Federal and State Governments should come up with mandatory training and retraining programme for business education lecturers so that they could have a good and caring teaching. The lecturers themselves should attend Association of Business Educators Nigeria conferences every year.

\section{References}

Arends, R. I. (1994). Learning to teach (3rd ed.) New York: McGraw-Hill, Inc.

Cooper, Ryan. (2010). International edition of those who can teach. Boston, USA: Wadsworth Cengage learning. 
Ellis, S., \& Tod, J. (2009). Behaviour for learning: proactive approaches to behaviour management. London and New York: Routledge Taylor and Francis group

Jordan, A., Carlile, O., \& Stack, A. (2008). Approaches to learning, a guide for teachers. McGraw Hill, Open university press.

Schiro, Michael Stephen. (2012). Curriculum theory: conflicting visions and enduring concerns. London: SAGE publications

Stephen, Patience. (2015). Good and effective teaching behaviours as perceived by business education students in colleges of education in Plateau State, unpublished B.ED project, Federal College of Education, Pankshin, Nigeria.

Udo, Magnus P. (2014). Acquisition of office technology and management skills for self-reliance. Asian Journal of management sciences and education, 3(4), 179-184. 